\title{
Physiological and Biochemical Significance of Genetically Modified Foods: An Overview
}

\author{
Sanjay Mishra, ${ }^{1, *}$ and R.B. Singh ${ }^{2}$ \\ ${ }^{1}$ School of Biotechnology, IFTM University, Lodhipur Rajput, Delhi Road (NH- 24), Moradabad 244 102, U.P., India \\ ${ }^{2}$ Halberg Hospital \& Research Center, Civil Lines, Moradabad 244 001, U.P., India
}

\begin{abstract}
Biotechnological discoveries and inventions have been observed to improve food production qualitatively as well as quantitatively. In certain specific cases, the improvement in the quality and nutrition of foods by altering their composition were also monitored. However, the practice of biotechnology has also upraised concerns about its potential risks to the environment as well as human being. Genetic Engineering provides resources to host genes into plants via mechanisms, different in some respects from classical breeding. A number of genetically engineered variety of foods have been developed, which have become important nutraceuticals; most notably canola, cotton, maize and soybean, were developed employing this modern technology, and at present the traits introduced are herbicide and/or pest tolerance. Gene technology leads to increase the production in plants, as well as the elevation of resistance to pests, viruses, frost, etc. Gene transfer technology is employed to alter the physical and chemical composition with nutraceutical worth. The present review article is the compilation of various physiological and biochemical studies reflecting both positive and negative ecological concerns of genetically modified foods.
\end{abstract}

Keywords: Allergy, Ecological concerns, Genetic Engineering, Genetically modified foods, Gene transfer technology, Plant Biotechnology.

\section{INTRODUCTION}

In fact, genetically modified organisms (GMOs) are demarcated as organisms (except for human beings), in which the genetic material has been transformed in a specific manner by mating and/or natural recombination. Organisms that have been genetically modified include micro-organisms such as bacteria and yeast, insects, plants, fish, and mammals [1-3]. GMOs are the principal source of genetically modified foods, and are thus widely used in scientific research and to produce goods other than food. The term GMO is having very much affinity towards technical legal term, 'living modified organism' defined in the Cartagena Protocol on Biosafety, reflecting to regulate international trade in living GMOs, specifically, "any living organism, which possesses a innovative amalgamation of genetic material achieved through the usage of modern biotechnology" [4-6]. GMOs have been monitored to show widespread applications as they are employed in biological and medical research, production of pharmaceutical drugs, experimental medicine, and agriculture [7-10]. The application of gene technology in food production has become fascinating due to amplified needs of food as well as its upgraded quality [11]. It is the fact that within the various applications in today's world, nature often concerns with geology and wildlife. Nature may

\footnotetext{
*Address correspondence to this author at the IFTM University, Lodhipur Rajput, Delhi Road (NH- 24), Moradabad 244 102, U.P., India;

Tel: +91-591-2360817; Fax: +91-591-2360818; Cell: +91-9837096059;

E-mail: sanjaymishra@iftmuniversity.ac.in
}

refer to the general aspect of different types of living plants and animals, and in some instances to the processes associated with inanimate -objects the way those particular types of things exist and alter their own worth, such as the weather and geology of the Earth, and the matter and energy of which all these things are composed. It is often considered to reflect the "natural environment" or wilderness-wild animals, rocks, forest, beaches, and commonly those things, which have not been substantially changed by human intervention, or which persist in spite of human intervention. For example, manufactured objects and human interaction generally are not considered part of nature, unless qualified as, for example, "human nature" or "the entire nature". This more traditional concept of natural things, which can still be found today implies a specific distinction between the natural and the artificial, with the artificial being understood as that which has been brought into being by a human consciousness or a human mind. Depending on the particular context, the term "natural" might also be distinguished from the unnatural, the supernatural, or synthetic ones. It is quite pertinent to demark the bridging between natural agricultural foods and modern synthetically designed foods very popular in modern era. With the proper application of gene technology to plants and animals goals can be attained more rapidly than by customary selection. Consequently ethical predicaments are opened concerning the ultimate negative effects of production of genetically modified foods. It gives the impression that supplementation of nutraceuticals and wild foods as well as wild lifestyle may be rather more protective, whereas 
western diet and lifestyle may enhance the expression of genes concerning with various chronic diseases. Human genes or physiological/biochemical pathways are most likely regulated by microRNA [12-15]. The occurrence and mortality due to multifactorial polygenic diseases such as hypertension, coronary artery disease (CAD), diabetes and cancer diverse contingent with genetic susceptibility and environmental forerunners because they have recognizable Mendelian subsets. Rapid alterations in diet and lifestyle may impact heritability of the variant phenotypes that are dependent on the nutraceutical or functional food supplementation for their specific expression. It is likely to recognize the collaboration of specific nutraceuticals, with the genetic code possessed by all nucleated cells. There is proof that South Asians have an amplified vulnerability to $\mathrm{CAD}$, diabetes mellitus, central obesity and insulin resistance at younger age that may be consequent to collaboration of gene and adverse nutrient environment [13]. The negative consequences can distress the health, environment, etiology, society and ultimately ethical issues $[14,15]$. The overview of studies accomplished so far along various notions and objectives concerning with physiological and biochemical parameters of genetically modified organisms and thus developed foods is as follows:

\section{DEVELOPMENT OF GENETICALLY MODIFIED ORGANISMS}

Various modern approaches of developing genetically modified organisms (GMO) are systematically acknowledged. The alien gene likely to be inserted into the cell of a microorganism, a plant or an animal is termed a transgene. It is incorporated into the genome of the recipients, recognized as transgenic. The incorporation of transgene into the cell is accomplished by various approaches: (i) Transduction with the use of bacteriophages [16-19] (ii) Transgene injection employing pronuclear microinjection [15]; (iii) Transfer employing altered viruses and plasmids [20, 21]; (d) Electroporation technique by which higher permeability of cell membrane attained [22-24].

For transfer of alien gene also non-natural chromosomes or fragments of chromosomes can be employed. Transgenes can be transferred into the egg-cell by spermatozoa comprising of fragments of chromosomes [14]. It is noticed that developed countries, having material and intellectual capacities, pointer the studies on transgenic technology for production upsurge and improved food quality. In fact, there is not only enough but even too much food in the developed world. However, developing countries that need this technology to exceed the food shortage cannot afford it $[25,26]$, thus leading towards the mandatory development of genetically modified organisms, most probably getting projected as 'nutraceuticals'.

\section{PROMOTION OF GM FOODS IN MODERN ERA}

'Genetic Engineering versus Agriculture' has been noticed to possess capability to produce plants with the exact anticipated trait very rapidly and with pronounced precision. Agriculture has frolicked a significant role in the development of human advancement - it is broadly thought that the up- gradation of plants and animals allowed humans to settle and give up their preceding hunter-gatherer lifestyle during the Neolithic Revolution. Until the Industrial Revolution, the enormous mainstream of the human population labored in agriculture. Development of agricultural practices has gradually augmented agricultural output, and the extensive dissemination of these procedures during a time period is often termed an agricultural revolution. A notable move in agricultural practices has arisen over the past century as a consequence of new technologies. Specifically, the Haber-Bosch technique for synthesizing ammonium nitrate made the oldfashioned exercise of recycling nutrients with crop rotation and animal manure less essential. Synthetic nitrogen, along with mined rock phosphate, pesticides and mechanization, has significantly amplified crop revenues in the early 20th century. Augmented supply of grains has directed to cheaper livestock as well. Besides, global yield upsurges were experienced later in the 20th century as and when high-yield varieties of common staple grains such as rice, wheat, and corn were presented as a part of the 'Green Revolution'. The 'Green Revolution' passed on the technologies, including principally synthetic nitrogen and pesticides of the developed world out to the developing world. Thomas Malthus famously predicted that the Earth would not be able to support its growing population, but technologies such as the 'Green Revolution' have shown to allow the world to yield an excess of food stuffs focusing on the up gradation of pigments especially carotenoids and apo-carotenoids [27]. Further, plant geneticists can segregate a gene accountable for drought tolerance and introduce that gene into a different plant. The new genetically-modified plant will gain drought tolerance as well [28]. Since two decades ago, when the first GM crops were introduced, there have increasingly been hot debates on the applications of gene manipulation. Presently, the development of GM crop varieties has raised a wide range of new legal, ethical and economic questions in agriculture. There is a growing body of literature reflecting the socio-economic and environmental impacts of GM crops aiming to criticize their value for farming schemes. While organic crops are encouraged as eco-friendly products in developed countries, they have motivated great disagreement in developing countries fronting food security and a low agricultural productivity. Debate has been specifically vital when organic farming was brought into practice as an alternative technique. There are in fact, a few compromises in developing countries. On the one hand, farmers are encouraged to accept and implement GM crops because of their higher yield, while on the other hand; organic farming is invigorated because of socio-economic and environmental deliberations. A key question fronting such countries is thus, whether GM crops can co-exist with organic farming. Not only can genes be transferred from one plant to another, but genes from non-plant organisms also can be bring into drill. The best recognized example of this is the use of B.t. genes in corn and other crops. B.t., or Bacillus thuringiensis, is a obviously occurring bacterium, generating certain specific crystal proteins, deadly to insect larvae. B.t. Crystal protein genes have been transferred into corn, endowing the corn to produce its own pesticides against insects.But this pesticide may also have adverse effect on human health on longterm consumption. 


\section{BENEFITS OF GM FOODS}

\section{Pest Resistance}

It has very often been noticed that genetically modified crops (GMCs, GM crops, or biotech crops) are plants, the DNA of which has been modified using genetic engineering techniques, to resist pests and certain specific agents causing harm to plants and to improve the growth of these plants to assist in farmers' efficacy. Genetic engineering techniques are much more precise [29] than mutagenesis (mutation breeding) where an organism is exposed to radiation or chemicals to create a non-specific but stable change. Other techniques by which humans modify food organisms include selective breeding; plant breeding, and animal breeding, and somaclonal variation. In most of the cases the major focus is to introduce a new trait to the plant which does not occur naturally in this species. Examples include resistance to certain pests, diseases or environmental conditions, or the production of a certain nutrient or pharmaceutical agent. Growing GM foods such as B.t. corn can help eliminate the application of chemical pesticides and reduce the cost of passing a harvest to market [30].

\section{Herbicide Tolerance and Disease Resistance}

Crop plants genetically-engineered to be resistant to one very powerful herbicide could help prevent environmental damage by reducing the amount of herbicides needed [3133 ], further reducing production cost concomitant with controlling the risk of agricultural waste run-off. There are a number of viruses, fungi and bacteria that cause plant diseases. In general, plant scientists, backed by results of modern comprehensive profiling of crop composition, point out that crops modified using GM techniques are less likely to have unintended changes than are conventionally bred crops [34]. With rather more advancement, plant biotechnologists are functioning to generate plants with geneticallyengineered resistance to these particular plant infections [35].

\section{Cold, Drought and Salinity Tolerance}

An antifreeze gene from cold water fish has been reported to be successfully introduced into plants such as tobacco and potato, enabling them to tolerate cold temperatures, usually killing unmodified seedlings [35]. Since the global population raises and more land is consumed for housing instead of food production, farmers will require to cultivate crops in localities previously unsuited for plant cultivation. Generating plants that can survive long periods of cold, drought or high salt content in soil and groundwater will aid populaces to grow crops in uncongenial dwellings $[36,37]$.

\section{Nutrition}

Undernourishment is very communal in third world countries where poor people trust in a single crop such as rice for the main staple of their diet. However, rice does not contain adequate amounts of all essential nutrients to avert malnutrition. If rice could be genetically engineered to contain additional vitamins and minerals with an adequate nutraceutical (physiological and biochemical) significance, nutrient shortages could be relieved. A successful study has been accomplished at the Swiss Federal Institute of Technology Institute for Plant Sciences leading to the development of "golden" rice comprising an unusually high content of beta-carotene (vitamin A) [38, 39]. Further studies along this specific notion and objective are underway to improve golden rice, also having increased iron content.

\section{Pharmaceuticals}

It is well known that medicines and vaccines often are costly enough to produce and sometimes require certain specific storage conditions. Continuous work along these specific line of action is on the way in view of developing certain edible vaccines in tomatoes and potatoes [40-42], probably will be rather easier to ship, store and administer compared to those pertaining to customary injectable vaccines [41].

\section{Phytoremediation}

Plants such as poplar trees [43] and safflower plants [44, 45] have been genetically engineered to upgrade the physiological and biochemical functioning relevant to cleaning up heavy metal pollution from contaminated soil in vicinity. Phytoremediation is the biotechnological application of plants to detoxify pollutants, and is a modern technique for environmental clean-up. Plants are ideal agents for soil and water remediation because of their unique genetic, biochemical and physiological features. Thus, the accumulation of mercury and Selenium was estimated in the roots, mature leaves and seeds of safflower (Carthamus tinctorius L), grown hydroponically in $10.4 \mathrm{M}$ solution for both phenyl mercuric acetate and selenium-dioxide for eight days. The tolerance was quantified followed by categorizing as: tolerant, partially tolerant and non-tolerant, employing the Response Coefficient parameter. Fifteen accessions as five each for tolerant, partially tolerant and non-tolerant were used for estimating the accumulation of various pollutants in roots, mature leaves and seeds, The data obtained from the studies [43- 45] provide new insights into products, which can be extracted with negligible concentration of mercury and selenium occurring in aerial parts of certain angiospermic economically and nutraceutically significant plants.

\section{DRAWBACKS OF GM FOODS}

Drawbacks of GM foods may principally be categorized as follows:

\section{Environmental Hazards}

Reduced effectiveness of pesticides just as some populations of mosquitoes developed resistance to the now-banned pesticide DDT; many people are having concern that insects will become resistant to B.t. or other crops that have been genetically modified to produce their own pesticides. Nevertheless, gene transfer to non-target species is another concern that crop plants engineered for herbicide tolerance and weeds will cross-breed, resulting in the transfer of the herbicide resistance genes from the crops into the weeds, most probably expressed as herbicide tolerant as well $[36,37]$. 


\section{Human Health Hazards}

It has been reported that a number of children in the US and Europe have developed life-threatening allergies to peanuts and other foods [46]. There is a likelihood that incorporating a gene into a plant may develop a new allergen or cause an allergic reaction in vulnerable individuals. A suggestion to slot in a gene from Brazil nuts into soybeans was abandoned for the reason of the fear of causing unpredicted allergic reactions [46]. Further, a recent article published in Lancet monitored the impacts of GM potatoes on the digestive tract in rats [47]. Moreover, the gene introduced into the potatoes was a snowdrop flower lectin, a substance known to be lethal to mammalian systems. It is factual that the yields of animal lectins are usually low compared with the yields of plant lectins such as legume lectins. Lectins manifest a diversity of activities including antitumor, immunomodulatory, antifungal, HIV-1 reverse transcriptase inhibitory, and antiinsect activities, which may find practical applications. A small number of lectins demonstrate antibacterial and antinematode activities [48].

\section{Economic Concerns}

It is indeed a prolonged and expensive practice to bring a GM food to the market, however consumer advocates are worried that patenting these new plant varieties will raise the price of seeds so high that small farmers and third world countries will not be able to afford seeds for GM crops, Patent enforcement may also be complicated, as the conflict of the farmers that they reluctantly used to grow Monsantoengineered strains [49]. In view of combatting probable patent contravention is to incorporate a "suicide gene" into GM plants. These plants would be feasible for only one growing season and would create sterile seeds, which do not germinate. Farmers would need to buy a fresh supply of seeds each year. Yet, this would be economically devastating for farmers [49]. Further, upon looking back over the past 50 years, or even over the past 100 years, economic growth has predominated. Over the longer term, it is noticed that people have become more prosperous, ultimately leading to the overall growth of world population. The natural assumption is that economic growth will continue in the future as it has in the past.

\section{RELEVANCE OF TRANSGENIC PLANTS TO HU- MAN NUTRITION}

GM foods are categorized based on their application and lawful policies [50] as: (a) Food is genetically modified (potato, tomato, soya, maize, sunflowers, rice, pumpkins, melons, rape, etc.); (b) Food comprises of components of genetically tailored plants (starch, sugar oil, vitamins proteins, aminoacids, antioxidants, minerals, etc.); (c) Food comprises of genetically adapted organisms. Gene technology enables higher production in plants, confrontation to pests and frost, as well as mechanical characteristics of fruits, etc. Further, physical and chemical profile can be modified in view of improving nutritional, physiological and biochemical value of foods. Transgenic plants also enable yield of more healthy food (more unsaturated fatty acids, transfer of proteins from legumes into wheat, augmented content of essential amino acids, transfer of proteins form sunflowers into maize, etc.).
In view of improving the quality-wise GM food production of cereal and grain legumes, biochemical and molecular level screening is mandatory to check and/or diminish risk of heart diseases, allergies and malignancy [51].

\section{PRINCIPAL GENETICALLY MODIFIED CROPS}

\section{Bt Cotton}

Cotton is a principal fibre crop of India being cultivated over an area of about 9.5 million hectares (mha) representing about one quarter of the worldwide area of 35 million hectares under this crop. Majority of this achievement possesses itself to the incorporation of $\mathrm{Bt}$ cotton in last decade prior to that cotton yield suffered vast losses consequent to its susceptibility to insects and pests. Insecticides esteemed at about US\$660 million are employed annually on all crops in India, of which about half are used on cotton alone [50,51]. $\mathrm{Bt}$ or Bacillus thuringiensis is a pervasive soil bacterium first revealed in 1901 by Ishiwata, a Japanese microbiologist [52]. Later it was registered that some $\mathrm{Bt}$ strains $(\mathrm{Cry}+)$ were highly toxic to larvae of definite insect species that are also plant pests. Successive research has exposed that Bt carries proteinaceous crystals that cause mortality in those insects that carry receptor proteins in gut membranes, which conjugate to $\mathrm{Bt}$ proteins. Other organisms, which do not contain receptors to Bt proteins are not exaggerated by the toxin molecules. The invention of genetic transformation technology enabled to insert cry genes and ultimately the ability to generate Bt proteins in plant cells, thus, the target insect larvae infesting the crop plants are effectively killed off. The first $\mathrm{Bt}$ crops viz., Bt cotton, Bt corn and $\mathrm{Bt}$ potato were commercialized in USA in 1996 [53]. It is further recognized that GM technology may entail rare unintended hazards to environment, and animal and human health. These hazards include toxicity and allergenicity, emergence of new viruses, development of antibiotic resistance in microorganisms, adverse effects on non-target organisms, erosion of crop diversity, and development of new weeds [54]. Bt cotton is in many means an ideal candidate for incorporation as a transgenic commercial crop. It is generally grown as a fibre crop, while cotton seed oil employed for utilization is free of proteins, including Bt protein. The safety of Bt toxins in relevance to toxicity and allergenicity towards mammals and other non-target organisms is well registered $[55,56]$. Lack of receptors, which bind to Bt toxins and their instant degradation in human digestive system enqables them innocuous to human beings. Community exposure to Bt spray formulations over a duration of about last sixty years has not led in any adverse impacts. Lack of homology to any allergenic protein/ epitope sequences enables Bt toxins non-allergenic. The safety of Bt crop-based foods has also been well documented $[57,58]$. Recently, the impacts of Bt crop cultivation on non-target organisms inclusive of insect predators, parasitoids and pathogens have been comprehensively studied and documented [59-62]. The efficacy of Bt crops against major pest species has been associated with an estimated about 137 million $\mathrm{kg}$ global reduction in insecticide active ingredient used between 1996 and 2006 (approximate 30\% reduction). Benefits fluctuate by country and region and are heavily weighted towards cotton production, which has historically been one of the largest users of insecticides in the world [63]. 


\section{Golden Rice}

Physiologically and biochemically, the bright orange of carrots comes from beta-carotene, forming vitamin A in human system. However, about 250 million people grieve from vitamin A deficiency. Consequently, every year about a half million children turn out to be blind from deficiency of vitamin A and over half of these decease within months. Idyllically, everyone would have a diverse diet with lots of produce that supplied plenty vitamin A and other nutrients.

Superior nutrition could avert up to two million deceases in children under the age of four every year. But that needs more wealth for much of the world - something, which is a lengthy way off. Approximately half the world's population lives on a daily bowl of white rice, containing no vitamin A. Enabling rice more nutritious, could improve people's lives enormously [64]. Besides, bioavailability of the carotene from golden rice has been confirmed and noticed to be an effective source of Vitamin A for human systems [65, 66].

\section{Potatoes}

A number of deprived countries have been observed not to afford vaccines. Clinics often cannot refrigerate the vaccines or sterilize needles. These problems make safeguarding millions of children tremendously problematic. Besides, utmost vaccines are prepared employing the infectious organism, causing the specific disease. In 1991 the World Health Organization challenged scientists to create a simpler, safer, cheaper way to vaccinate children. Some scientists instigated to brainstorm around plants. As plants obviously produce a number of diverse compounds, still obscure to explain whether they could be reprogrammed to create palatable vaccines [63]. It has been noticed that more than half the food in the grocery store contains GM derivatives, world hunger is at an all-time high, and there's a laundry list of disorders linked to consuming GM foods, including but not limited to autism and infertility.

\section{BT Brinjal}

In the end of first decade of 20th century, , the Genetic Engineering Approval Committee (GEAC) of the ministry of environment, the regulatory body for approving genetically modified crops (GM crops) in India, provided an approval to Bt brinjal, the first GM crop for human consumption in India, for commercial purpose [67]. The approval came in effect with subsequent review of reports acquiesced by the Maharashstra Hybrid Seeds Company Limited (Mahyco), which employes biotechnology to yield large quantity, pest resistant crops. Bt Brinjal is a genetically altered plant, in which a gene from the soil bacterium Bacillus thuringensis. is incorporated into the genome of the brinjal that can then yield a protein, Cry1Ac. This protein performs as a toxin against the shoot and fruit borer (SFB), a pest, commonly affecting brinjal. The gene alteration also comprises of the addition of two antibiotic confrontation indicator genes [67]. Thus, the results presented may raise some questions regarding the safety and acceptability of genetically engineered food, and provide some credence to the many consumers who are not yet prepared to accept food produced employing gene engineering techniques.

\section{GENETICALLYY MODIFIED ANIMALS VERSUS HUMAN NUTRITION}

Significant progression in fabrication and handling of transgenic plants has reinvigorated studies in animals [68]. Similar in plants, microinjection and parallel techniques are employed in view of injecting alien gene (DNA) into the nucleus of fertilized egg-cell in case of animals. Once egg is developed to blastula it is transported to the uterus of an animal where transgenic organism matures. Genetic linkage maps for cattle, pigs and sheep elucidating chromosomal areas for economically important qualities will noticeably pay to improved worth and quantities of meat [69]. Gene technology is well-off in farm animal production and in improvement of quality and quantity traits $[70,71]$. Gene technology motivates the productions, greater nutrient intake, and animal well-being. These individualities can be upgraded openly by gene transfer or employing growth hormones, vaccines, antibodies, immunity stimulants and antiallergy DNA created by genetic engineering. Gene transfer is anticipated to advance those fabrication traits in animals, which are ailing inherited (low heritability rate, h2), for example number of prevented piglets per sow [72] described that transgenic plants, which produced vaccines that animals consumed with forage, were formed. The gene for confrontation empowers breeding of animals impervious to diseases. Vaccine for immune castration of animals, effortless in male animals and weakens assertiveness while female animals are free of negative effects of oestrus, certainly affects the economically significant trait carcass conformation [73]. Nevertheless, transgenic milk can be used as: (a) Food for wide use; (b) raw materials for milk products; (c) food for infants; (d) source of biologically active substances for pharmaceutical industry [66]. Even non-protein compounds of human milk, like oligosaccharides, are extremely valued in milk of transgenic animals. Caseins and lactoglobulines are produced only during lactation period. Genes from mentioned compounds are employed for transgenic milk creation, beingused for cheese production and for auxiliary to human milk for the purpose of infant nutrition [66] described on wide consumption of bovine growth hormone (somatotropin) in cattle to escalating production of both, meat and milk [74]. Today there is still much to study about biology as well as genetic engineering concerning with human milk, and consequently there is much to work on the best composition of infant formulae in view of upgrading the human milk's quality using more and more precise practices regarding genetic transformation.

\section{HEALTH HAZARDS OF GENETICALLY MODIFIED ORGANISMS}

"A number of animal studies show serious health hazards connected with GM foods," comprising of infertility, immune problems, speeded aging, insulin regulation, and alterations in foremost organs and the gastrointestinal organization.

\section{GMOs VERSUS INHERENT HAZARDOUSNESS}

There are a number of causes of GM plants offering exceptional hazards [75]. The biotech industry confidently asserted that gene transfer from GM foods was not possible; 
the only human feeding study on GM foods later evidenced that it functions. The genetic material in soybeans that enables them herbicide tolerant transported into the DNA of human gut bacteria and continued to function $[75,76]$. This reflects that long after individuals stop eating a GM crop, its foreign GM proteins may be formed inside their bowels. The potential risks and benefits of the new technology to man and the environment are the major subjects to be reviewed. Further, Ways of minimizing potential risks and maximizing the benefits of GM foods are suggested. Because the benefits of GM foods apparently far outweigh the risks, regulatory agencies and industries involved in GM food business should increase public awareness in this technology to enhance worldwide acceptability of GM foods. This can be achieved through openness, education, and research.

\section{GM DIET SPECTACLES LETHAL REACTIONS IN THE DIGESTIVE TRACT}

The very leading crop submitted to the FDA's (Food \& Drug Administration) voluntary consultation process, the FlavrSavr tomato, exhibited confirmation of toxins. Out of twenty female rats fed the GM tomato, seven were reported to develop stomach lesions [77]. The form of stomach lesions associated to tomatoes could lead to life-threatening hemorrhage, predominantly in the elderly who use aspirin to preclude blood clots [78]. Further, mice fed potatoes engineered to produce the Bt-toxin developed atypical and damaged cells, as well as proliferative cell growth in the lower part of their small intestine [79]. Rats fed the GNA lectin potatoes had smaller and partially atrophied livers [80] Rats fed Monsanto's Mon 863 corn, engineered to produce Bttoxin, had liver lesions and other indications of toxicity [81] Rabbits fed GM soy showed altered enzyme production in their livers as well as higher metabolic activity $[82,83]$.

\section{REPRODUCTIVE DISASTER VERSUS INFANT MORTALITY}

The testicles of both mice and rats fed roundup ready soybeans exhibited intense alterations. In rats, the organs were dark blue instead of pink. In mice, young sperm cells were changed [84]. Besides, embryos of GM soy-fed mice also presented temporary alterations in their DNA function, compared to those whose parents were fed non-GM soy [85, 86].

\section{GM CROPS' TRIGGERRED IMMUNE REACTIONS VERSUS ALLERGIES}

Allergic reactions take place when the immune system infers somewhat as alien and reacts accordingly. All GM foods, by definition have something alien and different. Several studies indicate that they provoke reactions. GM potatoes instigated the immune system of rats to responded more gradually [80]. In addition to the herbicide lenient protein, GM soybeans contain a unique, unexpected protein that probably arose from the changes invited during the genetic engineering process. Scientists observed that this novel protein was able to bind with $\operatorname{IgE}$ antibodies, proposing that it may aggravate hazardous allergic reactions. Organic farmers and others have squirted crops with solutions encompassing natural $\mathrm{Bt}$ bacteria as a technique of for checking insects.
The toxin generates holes in their stomach and kills them. Genetic engineers take the gene, which that yields the toxin in bacteria and insert it into the DNA of crops so that the plant does the work, not the farmer. The point that human beings consume that toxic pesticide in every bite of Bt corn barely appetizing. Studies confirm, however that natural Bttoxin is not completely destroyed during digestion and does react with mammals. The $\mathrm{Bt}$ - toxin formed in GM crops is immensely unlike to the bacterial (Bt-toxins) employed in organic and old-fashioned farming and forestry. The plant created version is designed to be more toxic than natural varieties [87]. If $\mathrm{Bt}$ - toxin roots allergies, gene transfer transmits serious ramifications. Further, human intestinal flora may be rehabilitated into living pesticide factories, possibly producing Bt-toxin inside human system year after year, if Bt genes relocate to human gut bacteria [87].

\section{WELLBEING FEATURES OF GMO FOODS}

It has been well conversed whether the consumption of DNA in appropriate novel foods and novel foods constituents can be considered as safe as consumption of DNA in prevailing form [88]. Genetic modification consequences in the re-assortment of sequences of nucleotides leaving their chemical structures unchanged. Therefore, DNA from GMOs is chemically corresponding to any other DNA. The only inimitability is limited to variances in the DNA sequence that occurs also in natural disparities. The present application of recombinant practices in the food chain does not familiarize alterations in the chemical features of the DNA. There is no variance in the susceptibility of recombinant DNA and other DNA to filth by chemical or enzymatic hydrolysis. There are no signs that ingested DNA has allergenic or other immunogenic properties that would be of relevance for consumption of food consequential from GMOs. Uptake amalgamation and manifestation of any residual extracellular DNA fragments from foods by microorganisms of the gastrointestinal trait cannot be omitted. Each of these conditions is an unusual event and would have happen successively. In vivo uptake of DNA fragments by mammalian cells after oral administration has been perceived. There are operational mechanisms to evade genomic inclusion of alien DNA. There is no confirmation that DNA from dietary sources has ever been integrated into the mammalian genome [89] studied the animal nutrition with GMOs. However, some scientists [90] and advocacy groups such as Greenpeace and World Wildlife Fund contemplate that the existing data do not corroborate that GM food does not pose hazards to health, and call for additional and more rigorous testing before marketing genetically engineered food [91]. Worldwide, reports of allergies to all kinds of foods, particularly nuts, fish and shellfish, seem to be increasing, but it is not known if this reflects a genuine change in the risk of allergy, or an increased awareness of food allergies by the communities [91].

\section{REGULATION AND TAGGING OF TRANSGENIC FOODS}

Transgenic foods have previously appeared at European market. Hence some approaches of identification of these foods have been established $[63,64,91]$. Soy oil, beer, toma- 
toes, potatoes, maize, and certain spices are on the market. Gene transfer has been creating many conflicting and passionate debates particularly on the German spoken market. Some wide-ranging necessities on ample labeling of the genetically altered food in EU have been passed so that consumers can cherry-pick according to their ethical and medical trusts [91]. Advances in our understanding of physiology, molecular biology, biochemistry, and nutrition may in future allow further improvement of test methods that will over time render the safety assessment of foods even more effective and informative [92, 93]. The most important results from the EU-sponsored ENTRANSFOOD Thematic Network project have been reviewed, including the design of a detailed step-wise procedure for the risk assessment of foods derived from genetically modified crops based on the latest scientific developments, evaluation of topical risk assessment issues, and the formulation of proposals for improved risk management and public involvement in the risk analysis process. Further, these studies may include acute and repeated dose toxicology accomplishments and hypothesisbased testing. The application of these guidelines has been well documented using examples of transgenic proteins applied for agricultural input and output traits in genetically modified crops along with recommendations for future research considerations related to protein safety assessment $[92,93]$.

Conclusively, the latest expansion of physiology and biochemistry with a special focus on genetic engineering and transgenic technology has a very huge number of latent uses in food production, comprising micro-organisms, plants and animals. Genetic alteration has augmented production in some crops. Genetically modified foods have numerous benefits like high return, salinity tolerance, insect resistance etc. GM foods have a lot of health impacts on living beings. GM foods have both positive and negative impacts. These may be either direct effects, on organisms that feed on or interact with the crops, or wider effects on food chains produced by increases or decreases in the numbers of other organisms.

\section{DISCLOSURE}

This manuscript is an extended and updated version of the paper, "A Review on Impacts of Genetically Modified Food on Human Health The Open Nutraceuticals Journal, 2011, 4, 3-11',

\section{CONFLICT OF INTEREST}

The authors confirm that this article content has no conflicts of interest.

\section{ACKNOWLEDGEMENTS}

None declared.

\section{REFERENCES}

[1] Lee LY, Gelvin SB. T-DNA binary vectors and systems. Plant Physiol 2008; 146 (2): 325-32.

[2] Park F. Lentiviral vectors: are they the future of animal transgenesis? Physiol Genomics 2007; 31(2): 159-73.
[3] Cabot RA, Kühholzer B, Chan A, et al. Transgenic pigs produced using in vitro matured oocytes infected with a retroviral vector. Anim Biotechnol 2001; 12(2): 205-14.

[4] Nielsen KM. Transgenic organisms-time for conceptual diversification? Nat Biotechnol 2003; 21(3): 227-8.

[5] Schouten H, Krens F, Jacobsen E. Cisgenic plants are similar to traditionally bred plants: international regulations for genetically modified organisms should be altered to exempt cisgenesis. EMBO Rep 2006; 7(8): 750-3.

[6] Melo EO, Canavessi AMO, Franco MM, Rumpf R. Animal transgenesis: state of the art and applications. J Appl Genet 2007; 48(1): 47-61.

[7] Falck-Zepeda JB, Traxler G, Nelson RG. Surplus distribution from the introduction of a biotechnology innovation. Am J Agric Econ 2000; 82(2): 360-9.

[8] Shipitalo MJ, Malone RW, Owens LB. Impact of glyphosatetolerant soybean and glufosinate-tolerant corn production on herbicide losses in surface runoff. J Environ Qual 2008; 37(2): 401-8.

[9] Christou P, Capell T, Kohli A, et al. Recent developments and future prospects in insect pest control in transgenic crops. Trends Plant Sci 2006; 11(6): 302-8.

[10] Hutchison WD, Burkness EC, Mitchell PD, et al. Areawide suppression of European corn borer with $\mathrm{Bt}$ maize reaps savings to non-Bt maize growers. Science 2010; 330(6001): 222-5.

[11] Izquierdo J. Plant biotechnology and food security in Latin America and the Caribbean. Plant Biotechnol 2000; 3(1): 2225-32.

[12] Wong RWC,Sham M-H, Lau Y-L, Chan S-Y. An efficient method of generating transgenic mice. Mol Biotechnol 2000; 15: 155-9.

[13] Ruttloff H, Proll J, Leuchtenberger A. Lebensmittel Biotechnologie und Ernährung. Berlin: Springer-Verlag 1997; pp. 121-30.

[14] Singh RB, Niaz MA. Genetic variation and nutrition, in relation to coronary artery disease. J Assoc Phys India 1999; 47: 1185-90.

[15] Mishra S, Singh RB, Dwivedi SP, et al. Effect of nutraceuticals on genetic expressions. Open Nutraceuticals J 2009; 2: 70-80.

[16] Lujan S A, Guogas LM, Ragonese H, Matson SW, Redinbo MR. 2007 Disrupting antibiotic resistance propagation by inhibiting the conjugative DNA relaxase. Proc Natl Acad Sci USA 2007; 104(30): 12282-7.

[17] Petrescu-Mag IV, Bourne GR. Crossing-over between Y chromosomes: another possible source of phenotypic variability in the guppy, Poecilia reticulata Peters. Aquac Aquarium Conserv Legislation Int J Bioflux 2008; 1(1): 1-10.

[18] Perales-Graván C, Buendia JV, Lahoz-Beltra R. Modeling, simulation and application of bacterial transduction in genetic algorithms. Nat Preced 2009: 1-58.

[19] Carpa R. Genetic recombination in bacteria: horizon of the beginnings of sexuality in living organisms. Extrem Biospeol Astrobiol Int J Bioflux 2010; 2(1): 15-22.

[20] Wong SP, Argyros O, Coutelle C, Harbottle RP. Strategies for the episomal modification of cells. Curr Opin Mol Ther 2009; 11(4): 433-41.

[21] Haase R, Argyros O, Wong SP, et al. pEPito: a significantly improved non-viral episomal expression vector for mammalian cells. BMC Biotechnol 2010; 10: 433-41.

[22] Garcia PA, Rossmeisl JH, Neal RE, et al. Intracranial nonthermal irreversible electroporation: In vivo analysis. J Membr Biol 2010; 236(1): 127-36.

[23] Miklavčič D, Mir LM, Thomas VP. Electroporation-based technologies and treatments. J Membr Biol 2010; 236(1): 1-2.

[24] Thomson KR, Cheung Wa, Ellis SJ, et al. Investigation of the safety of irreversible electroporation in humans. J Vasc Interv Radiol 2011; 22(5): 611-21.

[25] Smolin L A, Grosvenor MB. Nutrition, science and applications. Fort worth: Harcourt College Publishers 2000.

[26] Andrew S, Daniel LS. Deep History: The architecture of past and present. USA: University of California Press 2011; p. 139.

[27] Rosati C, Diretto G, Giuliano G. Biosynthesis and engineering of carotenoids and apocarotenoids in plants: State of the art and future prospects. Biotechnol Genet Eng Rev 2009; 26: 151-74.

[28] Azadi H, Ho P. Genetically modified and organic crops in developing countries: A review of options for food security. Biotechnol Adv 2010; 28: 160-8.

[29] Bock R. The give-and-take of DNA: horizontal gene transfer in plants. Trends Plant Sci 2010; 15(1): 11-22. 
[30] Moellenbeck DJ, Peters ML, Bing JW, et al. Insecticidal proteins from Bacillus thuringiensis protect corn from corn rootworms. Nat Biotechnol 2001; 19(7): 668-72.

[31] Ohkawa H, Tsujii H, Ohkawa Y. The use of cytochrome P450 genes to introduce herbicide tolerance in crops: a review. Pestic Sci 1999; 55(9): 867-74.

[32] Gassmann AJ, Petzold-Maxwell JL, Keweshan RS, Dunbar MW. Field-evolved resistance to Bt maize by western corn rootworm. PLoS ONE 2011; 6: e22629.

[33] Federoff NV, Battisti DS, Beachy RN, et al. Radically rethinking agriculture for the 21st century. Science 2010; 327: 833-4.

[34] Catchpole GS. Hierarchical metabolomics demonstrates substantial compositional similarity between genetically modified and conventional potato crops. Proc Natl Acad Sci 2005; 102(40): 14458.

[35] Fairbairn D, Cavallaro A, Bernard M, et al. Host-delivered RNAi: an effective strategy to silence genes in plant parasitic nematodes. Planta 2007; 226(6): 1525-33.

[36] Kenward KD, Brandle J, Mc Pherson J, Davies PL. Type II fish antifreeze protein accumulation in transgenic tobacco does not confer frost resistance. Transgenic Res 1999; 8(2): 105-17.

[37] Zhang H-X, Blumwald E. Transgenic salt-tolerant tomato plants accumulate salt in foliage but not in fruit. Nat Biotechnol 2001; 19(8): 765-8.

[38] Tang W. Peroxidase activity of desiccation of tolerant loblollay pine somatic embryos. In Vitro Cell Dev Biol Plant 2000; 36(6): 488-91.

[39] Ye X, Al-Babili S, Klöti A, et al. Engineering the provitamin A (beta-carotene) biosynthetic pathway into (carotenoid-free) rice endosperm. Science 2000; 287(5451): 303-5.

[40] Perr HA. Oral immunization with hepatitis B surface antigen expressed in transgenic plants. Proc Natl Acad Sci USA 2001; 98(20): 11539-44.

[41] Mishra N, Gupta PN, Khatri K, et al. Edible vacccines: A new approach to oral immunization. Ind J Biotechnol 2008; 7: 283-94.

[42] Karaman S, Cunnick J, Wang K. Analysis of immune response in young and aged mice vaccinated with corn derived antigen Escherichia coli heat labile enterotoxin. Mol Biotechnol 2006; 32: 31 42.

[43] Ahmed M, Focht DD. Phytodetoxification of hazardous organomercurials by genetically engineered plants. Nat Biotechnol 2001; 18(2): 213-7.

[44] Madaan N, Mudgal V, Mishra S, Srivastava AK, Singh RB. Studies on biochemical role of accumulation of heavy metals in Safflower. Open Nutraceuticals J 2011; 4: 199-204.

[45] Mudgal V, Madaan N, Mudgal A, Singh RB, Mishra S. Effect of toxic metals on human health. Open Nutraceuticals J 2010; 3: 94-9.

[46] Nordlee JA, Taylor SL, Townsend JA, et al. Identification of a Brazil-nut allergen in transgenic soybeans. New Engl J Med 1996; 334(11): 688-92.

[47] Hartmann B, Subramaniam B, Zerner C. Effect of diets containing genetically modified potatoes expressing Galanthus nivalis lectin on rat small intestine. Lancet 1999; 354(9187): 1353-4.

[48] Lam SK, Ng TB. Lectins: production and practical applications. Appl Microbiol Biotechnol 2011; 89(1): 45-55.

[49] Naranjo S. Impacts of Bt crops on non-target invertebrates and insecticide use patterns. CAB Rev: Perspect Agric Vet Sci Nutr Nat Resour 2009; 4(11): 2009.

[50] Manjunath TM. Bt cotton in India: The technology wins as the controversy wanes. 2004. Available from: http://www.monsanto.co.uk/news/ukshowlib.html?wid $=8478$.

[51] Rai M, Acharya SS, Virmani SM, Aggrawal PK. State of Indian Agriculture. New Delhi: National Academy of Agricultural Sciences 2009.

[52] Kumar PA, Sharma RP, Malik VS. Insecticidal proteins of Bacillus thuringiensis. Adv Appl Microbiol 1996; 42: 1-43.

[53] James C. Global Status of Commercialized Biotech/GM Crops. ISAAA Briefs No. 39. Ithaca, NY: International Service for the Acquisition of Agri-Biotech Applications 2008.

[54] Gupta K, Karihaloo JL, Khetarpal RK. Biosafety Regulations in Asia-Pacific Countries. Bangkok: Asia-Pacific Association of Agricultural Research Institutions, New Delhi: Asia-Pacific Consortium on Agricultural Biotechnology, Rome: Food and Agricultural Organization of the United Nations 2008.

[55] Glare TR, O'Callaghan M. Bacillus thuringiensis: Biology, Ecology and Safety. New York: Wiley 2000.
[56] Betz FS, Hammond BG, Fuchs RL. Safety and advantages of Bacillus thuringiensis protected plants to control insect pests. Regul Toxicol Pharm 2000; 32: 156-73.

[57] OECD. Organization for Economic Co-operation and Development. Consensus document on safety information on transgenic plants expressing Bacillus thuringiensis derived insect control proteins. Paris: OECD 2007.

[58] Lemaux PG. Genetically engineered plants and foods: A scientist's analysis of the issues. Annu Rev Plant Biol 2008; 59: 771-812.

[59] Clark BW, Phillipes TA, Coates JR. Environmental fate and effects of Bacillus thuringiensis $(\mathrm{Bt})$ protein from transgenic crops: a review. J Agric Food Chem 2005; 53: 4643-53.

[60] Romeis J, Meissle M, Bigler F. Transgenic crops expressing Bacillus thuringiensis toxins and biological control. Nat Biotechnol 2006; 24: 63-71.

[61] Marvier M, McCreedy C, Regetz J, Kareiva P. A meta-analysis of effects of Bt cotton and maize on non-target invertebrates. Science 2007; 316: 1475-7.

[62] Babendreier D, Reichhart B, Romeis J, Bigler F. Impact of insecticidal proteins expressed in transgenic plants on bumblebee microcolonies. Entomol Exp Appl 2008; 126: 148-57.

[63] Naranjo SE. Impacts of Bt crops on non-target invertebrates and insecticide use patterns. CAB Reviews: Perspect Agric Vet Sci Nutr Nat Resour 2009; 4(11): 1-23.

[64] Magaña-Gómez JA, de la Barca AM. Risk assessment of genetically modified crops for nutrition and health. Nutr Rev 2009; 67(1): 1-16.

[65] Datta SK, Datta K, Parkhi V, et al. Golden rice: introgression, breeding, and field evaluation. Euphytica 2007; 154(3): 271-8.

[66] Tang G, Qin J, Dolnikowski GG, et al. Golden Rice is an effective source of vitamin A. Am J Clin Nutr 2009; 89(6): 1776-83.

[67] Menon S. Experts' panel approves Bt brinjal, final okay now with Jairam. Business Standard [Internet]. 2009 Oct 15 [cited 2009 Nov 27]. Available from: http://www.business-standard.com/india/news /experts/-panelapproves- bt-brinjal-final-okay-nowjairam/373318

[68] Berkowitz DB. The food safety of transgenic animals: Implications from traditional breeding. J Anim Sci 1993; 71: 43-6.

[69] Kappes SM . Utilization gene maping information in livestock animals. Theriogenology 1999; 51: 135-47.

[70] Bonneau M, Laarveld B. Biotechnology in animal nutrition, physiology and health. Livest Prod Sci 1999; 59: 223-41.

[71] Prieto PA, Kopchick JJ, Kelder B. Transgenic animals and nutrition research. J Nutr Biochem 1999; 10: 682-95.

[72] Mason HS, Ball IM, Shi JJ, Jiang X, Estes MK, Arntzen CJ. Expression of Norwalk virus capsid protein in transgenic tobacco and potato and its oral immunogenicity in mice. Proc Natl Acad Sci USA 1996; 93: 5335-40

[73] Remy JJ, Counture L, Rabesona H, Haertle T, Salesse R. Immunization against exon 1 decapeptides from the lutropin/choriogonatotropin receptor or the follitropin receptor as potential male contraceptive. J Reprod Immunol 1996; 32: 37-54.

[74] Solomon MB, Pursel VG, Paroczay EW, Bolt DJ. Lipid composition of carcass tissue from transgenic pigs expressing a bovine growth hormone gene. J Anim Sci 1994; 72: 1242-6.

[75] Netherwood T, Martín-Orúe SM, O'Donnell AG, et al. Assessing the survival of transgenic plant DNA in the human gastrointestinal tract. Nat Biotechnol 2004; 22: 2.

[76] Uzogara SG. The impact of genetic modification of human foods in the 21st century: A review. Biotechnol Adv 2000; 18: 179-206.

[77] Arpad Pusztai Genetically Modified Foods: Are They a Risk to Human/Animal Health? Action Bioscience. 2001. Available from: www.Actionbioscience.org/biotech/pusztai.httml.

[78] Fares NH, El-Sayed AK. Fine structural changes in the ileum of mice fed on endotoxin treated potatoes and transgenic potatoes. Nat Toxins 1998; 6: 219-33.

[79] Pusztai A. Can science give us the tools for recognizing possible health risk of GM food. J Nutr Health 2002; 16: 73-84.

[80] Tudisco R, Lombardi P, Bovera F, et al. Geneticallly modified soya bean in rabbit feeding: detection of DNA fragments and evaluation of metabolic effects by ezymatic analysis. J Anim Sci 2006; 82: 193-9.

[81] Burns JM. 13-week Dietary Subchronic Comparision study with Mon 863 Corn in rats Preceded by a 1-week Baseline Food Consumption Determination with PMI Certified Rodent Diet\#5002, December 17, 2002. 
[82] Vecchio L, Cisterna B, Malatesta M, Martin TE, Biggiogera M. Ultrastructural analysis of tests from mice fed on genetically modified soybean. Eur J Histochem 2004; 48(4): 449-54.

[83] Tudisco P, Lombardi F, Bovera D, et al. Genetically modified soya bean in rabbit feeding: Detection of DNA fragments and evaluation of metabolic effects by enzymatic analysis. Anim Sci 2006; 82: 193-9.

[84] Oliveri J. Temporary Depression of Transcription in mouse Preimplantation Embryos from mice fed onGenetically Modified Soybean. $48^{\text {th }}$ Symposium of the Society for histochemistry, Lake Magggiore: Italy, September 7-10, 2006.

[85] Dutton A, Klein H, Romeis J, Bigler F. Uptake of Bt-toxin by herbivores feeding on transgenic maize and consequences for the predator Chrysoperia carnea. Ecol Entomol 2002; 27: 441-7.

[86] Ermakova IV. GMO: Life itself intervened into the experiments. Letter, Ecos Inform 2006; N2: 3-4.

[87] Jonas DA, Elmadfa I, Engel KH, et al. Safety considerations of DNA in food. Ann Nutr Metab 2001; 45: 235-54.
[88] Flachowsky A, Aulrich K. Lebensmittel tierischer Herkunft nach Einsatz von Futtermitteln aus gentechnisch veränderten Pflanzen (GVP). Ernäru Umsch 2002; 3: 84-93.

[89] NRC. Safety of Genetically Engineered Foods: Approaches to Assessing Unintended Health Effects. USA: National Academies Press 2004.

[90] Vendômois D, Spiroux J, Roullier F, Cellier D, Séralini GE. A comparison of the effects of three gm corn varieties on mammalian health. Int J Biol Sci 2009; 5: 706-26.

[91] Kuehn BM. Food allergies becoming more common. JAMA 2008; 20: 2358 .

[92] Konig A, Cockburn A, Crevel RWR, et al. Assessment of the safety of foods derived from genetically modified (GM) crops. Food Chem Toxicol 2004; 42: 1047-88.

[93] Bradford KG, Van Deynze A, Gutterson N, et al. Regulating transgenic crops sensibly: lessons from plant breeding, biotechnology and genomics. Nat Biotechnol 2005; 23: 439-44.

(C) Mishra and Singh; Licensee Bentham Open.

This is an open access article licensed under the terms of the Creative Commons Attribution Non-Commercial License (http://creativecommons.org/licenses/by-nc/3.0/) which permits unrestricted, non-commercial use, distribution and reproduction in any medium, provided the work is properly cited. 